\title{
PENGARUH MODEL PEMBELAJARAN CREATIVE PROBLEM SOLVING TERHADAP KEMAMPUAN LITERASI MATEMATIS SISWA SMA
}

\author{
Rohana $^{1}$, Yusuf Hartono ${ }^{2}$, Imam Adhitya Nugraha ${ }^{3}$ \\ Program Studi Pendidikan Matematika Universitas PGRI Palembang ${ }^{1,3}$ \\ Program Studi Pendidikan Matematika Universitas Sriwijaya ${ }^{2}$ \\ rohana_pgri@yahoo.com ${ }^{3}$
}

\begin{abstract}
ABSTRAK
Tujuan Penelitian ini adalah untuk mengetahui pengaruh model pembelajaran Creative Problem Solving terhadap kemampuan literasi matematis siswa SMA Negeri 6 Prabumulih. Metode yang digunakan dalam penelitian ini adalah metode eksperimen dengan Posttest-Only Control Design. Populasi dalam penelitian ini adalah seluruh siswa kelas XI SMA Negeri 6 Prabumulih berjumlah 276 siswa yang terdiri 5 kelas XI.MIPA dan 3 XI.IPS pada tahun pelajaran 2019/2020. Sampel diambil dengan teknik Cluster Sampling, diperoleh kelas XI.MIPA.3 sebagai kelas eksperimen yang diajarkan dengan model pembelajaran Creative Problem Solving dan kelas XI.MIPA.1 sebagai kelas kontrol yang diajarkan dengan pembelajaran konvensional. Teknik pengumpulan data menggunakan tes kemampuan literasi matematis siswa Level 3. Data dianalisis dengan menggunakan uji t. Kesimpulan dari penelitian ini adalah ada pengaruh yang signifikan model pembelajaran Creative Problem Solving terhadap kemampuan literasi matematis siswa SMA Negeri 6 Prabumulih.
\end{abstract}

Kata kunci : creative problem solving, literasi matematis

\begin{abstract}
The aim of this study was to see how the Creative Problem Solving learning model affected the mathematical literacy skills of SMA Negeri 6 Prabumulih students. This study used an experimental method with a Posttest-Only Control Design. In this study, the population consisted of all students from class XI SMA Negeri 6 Prabumulih, a total of 276 students from 5 classes XI.MIPA and 3 XI.IPS in the 2019/2020 school year. The sample was obtained using the Cluster Sampling technique, with class XI.MIPA.3 serving as an experimental class taught with the Creative Problem Solving learning model and class XI.MIPA.1 serving as a control class taught with conventional learning. The data was gathered using a mathematical literacy ability test administered to a level 3 student. The t-test was used to analyze the data. This study concludes that the Creative Problem Solving learning model has a significant effect on the mathematical literacy ability of SMA students.
\end{abstract}

Keyword : creative problem solving, mathematical literacy 


\section{PENDAHULUAN}

Perkembangan di era industri revolusi 4.0 telah mengubah cara seseorang dalam belajar, mengubah sifat pekerjaan yang dulu secara manual menjadi berbasis komputer. Selain itu di Era Industri Revolusi 4.0, suatu teknologi dapat memberikan dampak perubahan pada makna hubungan sosial yang jauh menjadi lebih dekat tanpa terkendala jarak.

Pada era industri revolusi 4.0 pengambilan keputusan bersama, beradaptasi dan berinovasi menjadi salah satu aspek yang sangat penting. Oleh karena itu, sekolah ditantang untuk membuat siswa memiliki kecakapan agar berkomunikasi menjadi lebih mudah, cepat dan tanpa batasan, memudahkan akses informasi, mempersingkat waktu, berbagi informasi secara efektif serta memecahkan masalah yang komprehensif dengan menggunakan teknologi, beradaptasi dan berinovasi serta memperkaya kemampuan teknologi untuk menciptakan pengetahuan baru. Untuk membantu menjawab tantangan ini, pemerintah menginisasi terbentuknya era industri revolusi 4.0.

Pada era industri revolusi 4.0 terdapat 10 sepuluh keterampilan yang harus dimiliki seorang untuk dapat sukses, yaitu: 1) Complex Problem Solving; 2) Critical Thingking; 3) Creativity; 4) People Management; 5) Coordinat with Other; 6) Emotion Intelligence; 7) Judgement and Descision Making; 8) Service Orientation; 9) Negotitation; dan 10) Cognitive Flexibility (Gray, 2016). Selain sepuluh keterampilan di atas Effendy (2018) menambahkan bahwa rasa percaya diri merupakan modal yang sangat dibutuhkan siswa untuk dapat bergaul pada era industri revolusi 4.0 .

Berdasarkan paparan di atas, dapat diketahui bahwa keterampilan pemecahan masalah yang komprehensif atau Complex Problem Solving merupakan keterampilan yang paling atas di era Industri Revolusi 4.0. Complex Problem Solving sangat penting untuk dimiliki siswa agar dapat memecahkan masalah secara komplek, semakin berkembangnya teknologi digital maka kualitas masalah yang muncul dari dampak perkembangan tersebut menjadi semakin rumit (Perdana, 2019). Keterampilan Complex Problem Solving tidak dapat lepas dari tingkat pengetahuan siswa. Pengetahuan dihasilkan dari seberapa ilmu pengetahuan didapat dari informasi yang diperoleh baik secara lisan maupun tulisan, maka informasi yang diperoleh melalui tulisan tentu saja didapat dari kegiatan membaca dan menulis. Dengan demikian dibutuhkan kemampuan literasi untuk memahami dan menguasai informasi tersebut.

Salah satu kemampuan literasi yang diperlukan bagi siswa yaitu kemampuan literasi matematis. OECD (2015) menyatakan bahwa literasi matematis sebagai kemampuan individual untuk memformulasikan, menggunakan, dan menafsirkan matematika dalam berbagai konteks, dengan meliputi penggunaan konsep, prosedur, fakta dalam matematika yang dapat mengembangkan kemampuan dan kepercayaan diri untuk berpikir secara numerik dan spasial dalam menafsirkan dan menganalisa serta memecahkan masalah suatu fenomena sehari-hari secara kritis agar lebih siap menghadapi tantangan kehidupan. Sedangkan Ojose (2011) menyatakan bahwa kemampuan literasi matematis merupakan pengetahuan untuk mengetahui dan menggunakan dasar matematika dalam kehidupan sehari-hari. Dalam pengertian ini, menunjukkan bahwa seseorang yang memiliki kemampuan literasi matematis yang baik memiliki kepekaan terhadap konsep-konsep matematika mana yang relevan 
dengan masalah yang dihadapinya. Dari kepekaan tersebut kemudian dilanjutkan dengan pemecahan masalah dengan menggunakan konsep matematika.

Saat ini salah satu penilaian yang menjadi patokan internasional dalam mengukur kemampuan literasi siswa yaitu PISA. PISA (Program for International Student Assessment) merupakan sebuah penilaian secara internasional yang diselenggarakan oleh OECD terhadap keterampilan serta kemampuan siswa usia 15 tahun (Shile et all., 2007) dimana usia siswa di sebagian besar negara mendekati akhir dari wajib belajar (Stacey, 2011). Keterampilan dan kemampuan dalam PISA yang dinilai meliputi matematika, membaca, dan sains (Stacey, 2011). PISA pertama kali dilaksanakan pada tahun 2000 dan dilaksanakan 3 tahun sekali (Shiel et al., 2007). Pada PISA 2015 terdapat 3 kategori proses yaitu formulate, employ, dan interprete yang digambarkan dalam model literasi matematis pada Gambar 1 (Abidin dkk, 2017) berikut ini:

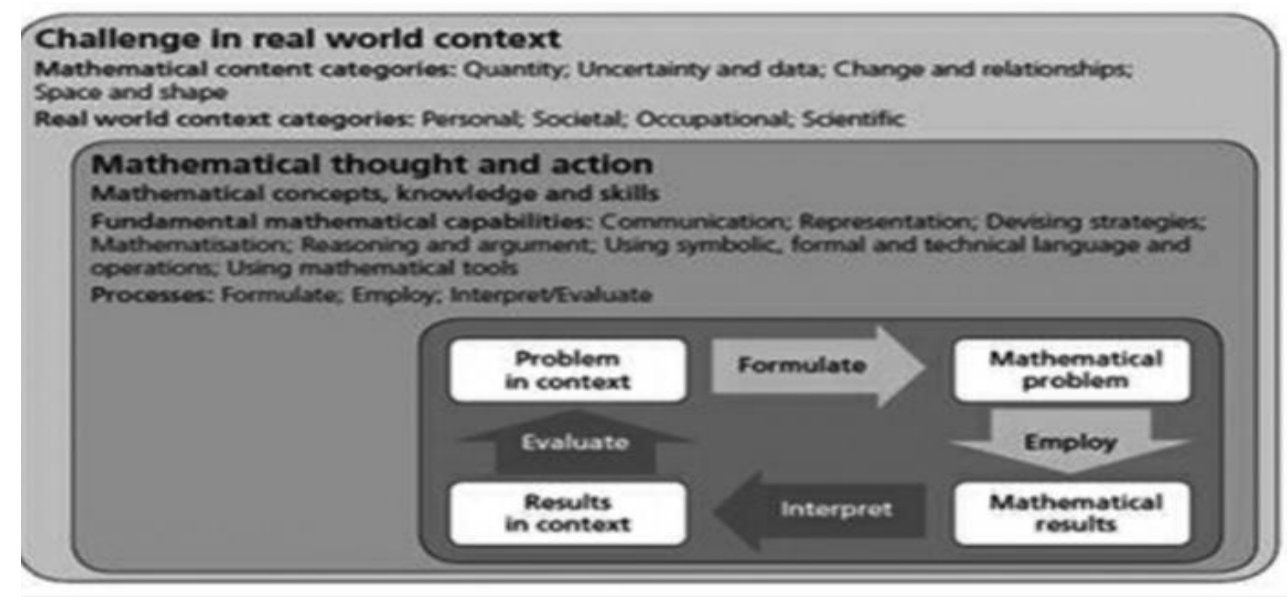

Gambar 1. Tahapan literasi matematis

Literasi matematis siswa dalam PISA terbagi menjadi 6 tingkatan atau 6 level. Tipe soal literasi matematis pada level 1 dan 2 termasuk kelompok soal dengan skala bawah yang mengukur kompetensi reproduksi yang disusun berdasarkan konteks yang sudah dikenal oleh siswa dengan operasi matematika yang sederhana. Tipe soal literasi matematis pada level 3 dan 4 termasuk kelompok soal dengan skala menengah yang mengukur kompetensi koneksi yang diperlukan interpretasi siswa karena situasi yang diberikan tidak dikenal atau bahkan belum pernah dialami oleh siswa. Tipe soal literasi matematis pada level 5 dan 6 termasuk kelompok soal dengan skala tinggi karena mengukur kompetensi refleksi yang menuntut penafsiran tingkat tinggi dengan konteks yang sama sekali tidak terduga oleh siswa (Jumarniati, dkk, 2016).

Kemendikbud (2016) menyatakan bahwa PISA merupakan sistem ujian yang diselenggarakan oleh Organication for Economic Cooperation and Development (OECD) untuk mengevaluasi sistem pendidikan dari 72 negara di seluruh dunia, setiap tiga tahun siswa berusia 15 tahun dipilih secara acak untuk mengikuti tiga tes yaitu kompetensi membaca, matematika, dan sains. Berdasarkan nilai rerata terjadi suatu peningkatan dalam nilai PISA Indonesia dalam tiga kompetensi yang diujikan. Dalam kompetensi sains sebesar 403 poin di tahun 2015, kompetensi matematika sebesar 386 poin di tahun 2015, dan kompentensi membaca sebesar 397 poin di 
tahun 2015. Sedangkan berdasarkan nilai media, capaian membaca siswa di Indonesia sebesar 350 poin di tahun 2015, nilai matematika sebesar 335 poin di tahun 2015, dan capaian sains sebesar 359 poin di tahun 2015. Adapun skor PISA dan peringkat Indonesia dibandingkan dengan negara partisipan dapat dilihat pada Tabel 1.

Tabel 1. Skor PISA dan peringkat Indonesia dibandingkan dengan negara OECD

\begin{tabular}{ccccc}
\hline Tahun & Skor Indonesia & Skor internasional & Rank & Total negara partisipan \\
\hline 2000 & 367 & 500 & 39 & 41 \\
2003 & 361 & 500 & 38 & 40 \\
2006 & 391 & 500 & 50 & 57 \\
2009 & 371 & 500 & 57 & 63 \\
2012 & 375 & 500 & 64 & 65 \\
2015 & 386 & 500 & 62 & 72 \\
\hline
\end{tabular}

(Sumber : OECD, 2015)

Berdasarkan Tabel 1 menunjukkan bahwa capaian literasi matematis siswa di Indonesia masih di bawah rerata negara-negara OECD. Rendahnya literasi tersebut diukur dengan menggunakan instrumen yang berlaku secara internasional dan tidak spesifik disesuaikan dengan kondisi Indonesia. Misalnya, terdapat butir soal yang menggunakan stimulus mengenai subway (kereta api bawah tanah) yang tidak familiar bagi anak Indonesia, studi PISA 2015 menggunakan banyak sekali konteks asing yang belum dikenal oleh siswa kita di pelosok daerah misalnya skateboard, kereta maglev, ataupun sistem telepon di hotel dan kartu elektronik (Fathani, 2016).

Kemampuan literasi matematis siswa Indonesia memang masih rendah, seperti yang dinyatakan Putra dkk (2016) bahwa kemampuan literasi matematika siswa Lampung masih rendah dalam menyelesaikan soal-soal model PISA level 4, 5, dan 6, hal ini terlihat dari hasil penelitiannya didapatkan hanya 20,45\% dari 330 (22x15) butir jawaban yang dianalisis yang terindentifikasi sebagai jawaban benar.

Termasuk juga siswa SMA Negeri 6 Prabumulih, berdasarkan hasil wawancara dengan guru mata pelajaran matematika diperoleh bahwa kemampuan literasi matematis siswa tergolong sangat rendah, kebanyakan siswa belum mampu menafsirkan masalah matematika yang berbentuk cerita, apalagi ceritanya cukup panjang. Dilihat dari cara mengajar guru di sekolah ini, guru masih menggunakan model pembelajaran konvensional (pembelajaran dua arah yaitu antara guru dan siswa) karena guru masih sulit untuk merancang model pembelajaran.

Salah satu upaya yang dapat dilakukan oleh guru dalam meningkatkan kemampuan literasi siswa adalah melakukan inovasi pembelajaran matematika. Model pembelajaran yang diduga dapat digunakan untuk memperbaiki kemampuan literasi matematika yaitu model pembelajaran Creative Problem Solving (CPS). Model pembelajaran Creative Problem Solving (CPS) adalah suatu model pembelajaran yang dilakukan pemusatan pada pengajaran dan keterampilan pemecahan masalah, yang diikuti dengan penguatan keterampilan. Model pembelajaran CPS memiliki langkah-langkah yang terdiri dari 4 tahapan yaitu: 1) Klasifikasi masalah; 2) Pengungkapan pendapat; 3) Evaluasi dan pemilihan; dan 4) Implementasi (Shoimin, 2014). 
Dilihat dari penelitian sebelumnya yang dilakukan oleh Fitriyani dan Mastur (2017) menunjukkan bahwa kemampuan literasi matematika siswa pada kelas yang diajar dengan model pembelajaran CPS berbantuan Hand on Acitivity lebih baik daripada kemampuan literasi matematika siswa pada kelas yang diajar dengan model pembelajaran konvensional. Juga berdasarkan penelitian yang dilakukan oleh Wahyuni, Mariyam, dan Sartika (2018) bahwa kemampuan berpikir kritis matematis siswa yang diajarkan dengan model pembelajaran Creative Problem Solving (CPS) telah mencapai ketuntasan secara individu maupun klasikal. Oleh karena itu, berdasarkan pemaparan dan kajian penelitian relevan yang diuraikan di atas, maka perlu dilakukan penelitian lebih banyak lagi tentang pengaruh penggunaan model pembelajaran Creative Problem Solving terhadap kemampuan literasi matematis siswa khususnya bagi siswa SMA Negeri 6 Prabumulih.

\section{METODE}

Metode yang digunakan dalam penelitian ini adalah metode ekperimen dengan desain Posttest-Only Control Design. Teknik pengambilan sampel menggunakan Cluster Sampling yaitu secara acak terpilih dua kelas dari populasi (Sugiyono, 2017).

\begin{tabular}{|lll|}
\hline $\mathrm{R}$ & $\mathrm{X}$ & $\mathrm{O}_{2}$ \\
$\mathrm{R}$ & & $\mathrm{O}_{4}$ \\
\hline
\end{tabular}

Gambar 2. Posttest-only control grup design

Keterangan:

$\mathrm{R}$ : kelompok sampel yang dipilih secara random

$\mathrm{X}$ : perlakuan (model pembelajaran Creative Problem Solving)

$\mathrm{O}_{2}$ : postes pada kelompok yang diberikan perlakuan

$\mathrm{O}_{4}$ : postes pada kelompok yang tidak diberikan perlakuan

Populasi dalam penelitian ini adalah seluruh siswa kelas XI SMA Negeri 6 Prabumulih tahun pelajaran 2019/2020 semester ganjil yang berjumlah 276 siswa. Sampel terpilih yaitu kelas XI.MIPA.3 sebagai kelas eksperimen dan kelas XI.MIPA.1 sebagai kelas kontrol. Penelitian dilaksanakan pada 29 Juli sampai dengan 30 Agustus 2019.

Pengukuran dilakukan pada tes kemampuan literasi matematis level 3. Tes yang digunakan berupa uraian yang disusun berdasarkan indikator kemampuan literasi matematis level 3 dan telah melalui validasi pakar, uji validitas, dan uji reliabel. Tes kemampuan literasi matematis level 3 diberikan di akhir pembelajaran, dengan materi yang dipilih dalam penelitian ini adalah Program linear. Menurut Jufri (2014) literasi matematis pada proses adalah kemampuan siswa dalam merumuskan (formulate), menggunakan (employ), dan menafsirkan (interpret) untuk memecahkan masalah. Pedoman penskoran literasi matematis pada proses diadopsi dari Antika (2015) dengan indikator dalam mengukur kemampuan literasi matematis sebagai berikut: 
Tabel 2. Indikator kemampuan literasi matematis level 3

\begin{tabular}{|c|c|c|c|}
\hline $\begin{array}{l}\text { Kemampuan pada } \\
\text { komponen proses }\end{array}$ & Indikator & Respon siswa & Skor \\
\hline \multirow{4}{*}{ Merumuskan } & \multirow{4}{*}{$\begin{array}{l}\text { Mengidentifikasi } \\
\text { fakta-fakta dan } \\
\text { merumuskan } \\
\text { masalah }\end{array}$} & $\begin{array}{c}\text { Tidak ada mengindentifikasi } \\
\text { fakta-fakta dan merumuskan } \\
\text { masalah }\end{array}$ & 0 \\
\hline & & $\begin{array}{l}\text { Mengindentifikasi namun } \\
\text { kurang jelas dan kurang tepat }\end{array}$ & 1 \\
\hline & & $\begin{array}{l}\text { Mengindentifikasi fakta-fakta } \\
\text { tetapi kurang lengkap dan } \\
\text { merumuskan masalah lengkap } \\
\text { tetapi belum tepat }\end{array}$ & 2 \\
\hline & & $\begin{array}{l}\text { Mengindentifikasi fakta-fakta } \\
\text { dan merumuskan masalah } \\
\text { dengan lengkap, jelas dan benar }\end{array}$ & 3 \\
\hline \multirow{4}{*}{$\begin{array}{l}\text { Mampu menggunakan } \\
\text { konsep, fakta prosedur } \\
\text { dan penalaran } \\
\text { matematika }\end{array}$} & \multirow{4}{*}{$\begin{array}{c}\text { Strategi yang } \\
\text { digunakan pada } \\
\text { tahapan } \\
\text { penyelesaian } \\
\text { masalah }\end{array}$} & $\begin{array}{l}\text { Tidak ada menggunakan strategi } \\
\text { pada tahapan penyelesaian } \\
\text { masalah }\end{array}$ & 0 \\
\hline & & $\begin{array}{l}\text { Memilih strategi yang tidak } \\
\text { tepat dan tidak lengkap pada } \\
\text { penyelesaian masalah }\end{array}$ & 1 \\
\hline & & $\begin{array}{l}\text { Memilih strategi yang tepat } \\
\text { tetapi tidak lengkap pada } \\
\text { penyelesaian masalah }\end{array}$ & 2 \\
\hline & & $\begin{array}{l}\text { Memilih strategi tepat pada } \\
\text { tahapan penyelesaian masalah } \\
\text { dengan lengkap dan benar }\end{array}$ & 3 \\
\hline \multirow{4}{*}{$\begin{array}{l}\text { Mampu menggunakan } \\
\text { konsep, fakta prosedur } \\
\text { dan penalaran } \\
\text { matematika }\end{array}$} & \multirow{4}{*}{$\begin{array}{l}\text { Melaksanakan } \\
\text { perhitungan } \\
\text { berdasarkan } \\
\text { aturan atau } \\
\text { rumus tertentu }\end{array}$} & $\begin{array}{c}\text { Tidak ada melaksanakan } \\
\text { perhitungan berdasarkan atau } \\
\text { rumus tertentu }\end{array}$ & 0 \\
\hline & & $\begin{array}{c}\text { Melaksanakan perhitungan } \\
\text { tetapi salah }\end{array}$ & 1 \\
\hline & & $\begin{array}{l}\text { Melaksanakan perhitungan } \\
\text { tetapi sebagian yang benar }\end{array}$ & 2 \\
\hline & & $\begin{array}{c}\text { Melaksanakan perhitungan } \\
\text { dengan jelas dan benar }\end{array}$ & 3 \\
\hline \multirow{4}{*}{$\begin{array}{c}\text { Menafsirkan } \\
\text { matematika untuk } \\
\text { memecahkan masalah }\end{array}$} & \multirow{4}{*}{$\begin{array}{c}\text { Menegaskan / } \\
\text { menarik } \\
\text { kesimpulan dari } \\
\text { satu kasus } \\
\text { berdasarkan } \\
\text { sejumlah data } \\
\text { yang teramati }\end{array}$} & $\begin{array}{l}\text { Tidak membuat kesimpulan dari } \\
\text { kasus berdasarkan sejumlah data } \\
\text { teramati }\end{array}$ & 0 \\
\hline & & $\begin{array}{c}\text { Membuat kesimpulan yang tidak } \\
\text { tepat dan tidak sesuai dengan } \\
\text { data teramati }\end{array}$ & 1 \\
\hline & & $\begin{array}{l}\text { Membuat kesimpulan dengan } \\
\text { tepat tetapi tidak lengkap }\end{array}$ & 2 \\
\hline & & $\begin{array}{c}\text { Membuat kesimpulan dengan } \\
\text { tepat, sesuai dengan data } \\
\text { teramati dan lengkap }\end{array}$ & 3 \\
\hline
\end{tabular}


Setelah mendapatkan tes kemampuan literasi matematis level 3 dilanjutkan dengan menganalisis data. Analisis data dalam penelitian ini menggunakan Uji Independent Sample T-Test (Kesumawati dan Aridanu, 2018). Sebelum data dianalisis, akan dilakukan terlebih dahulu uji prasyarat berupa uji normalitas dan uji homogenitas. Setelah data dinyatakan normal dan homogen maka dilanjutkan dengan uji Independent Sample T-Test. Semua pengolahan data menggunakan bantuan software SPSS 22.

\section{HASIL DAN PEMBAHASAN}

Dalam penelitian ini yang menjadi indikator kemampuan literasi matematis level 3 sebagai berikut: 1) Mengindentifikasi fakta-fakta dan merumuskan masalah; 2) Strategi yang digunakan pada tahapan penyelesaian masalah; 3) Melaksanakan perhitungan berdasarkan aturan atau rumus tertentu; dan 4) Menegaskan kesimpulan dari satu kasus berdasarkan sejumlah data yang teramati.

Data hasil tes akhir dianalisis dengan mengacu pada kemampuan literasi matematis level 3 tersebut. Hasil tes akhir siswa perindikator kemampuan literasi matematis level 3 pada siswa di SMA Negeri 6 Prabumulih dapat dilihat pada Tabel 3 berikut.

Tabel 3. Perbandingan berdasarkan indikator kemampuan literasi matematis level 3 siswa SMA Negeri 6 Prabumulih

\begin{tabular}{clcccc}
\hline No & \multicolumn{1}{c}{ Indikator } & \multicolumn{2}{c}{ Eksperimen } & \multicolumn{2}{c}{ Kontrol } \\
\cline { 3 - 6 } & Jumlah & Mean & Jumlah & Mean \\
\hline 1. & $\begin{array}{l}\text { Mengindentifikasi fakta-fakta } \\
\text { dan merumuskan masalah }\end{array}$ & 194 & 92,38 & 181 & 86,19 \\
2. & $\begin{array}{l}\text { Strategi yang digunakan pada } \\
\text { tahapan penyelesaian masalah }\end{array}$ & 187 & 89,05 & 171 & 81,43 \\
3. $\begin{array}{l}\text { Melaksanakan perhitungan } \\
\text { berdasarkan aturan atau rumus } \\
\text { tertentu }\end{array}$ & 166 & 79,05 & 150 & 71,43 \\
4. Menegaskan kesimpulan dari \\
$\begin{array}{l}\text { satu kasus berdasarkan sejumlah } \\
\text { data yang teramati }\end{array}$ & 79 & 75,24 & 63 & 60,00 \\
\hline & 626 & 85,17 & 565 & 76,87 \\
\hline
\end{tabular}

Dari analisis data tes yang ditunjukkan Tabel 3, diperoleh kemampuan literasi matematis siswa pada level 3 dengan menggunakan model pembelajaran Creative Problem Solving (CPS) lebih baik daripada pembelajaran konvensional. Rata-rata nilai setiap indikator kemampuan literasi matematis siswa pada kelas eksperimen melebihi rata-rata nilai siswa pada kelas kontrol.

Hal ini juga dilihat dari deskripsi data hasil tes kemampuan literasi matematis level 3 di SMA Negeri 6 Prabumulih pada Tabel 4 berikut.

Tabel 4. Deskripsi kemampuan literasi matematis level 3 siswa SMA Negeri 6 Prabumulih

\begin{tabular}{lcc}
\hline \multicolumn{1}{c}{ Statistik } & Kelas \\
& Eksperimen & Kontrol \\
\hline Jumlah siswa & 35 & 35 \\
Skor ideal & 100 & 100 \\
Minimum (X min) & 67 & 48
\end{tabular}




\begin{tabular}{lcc} 
Maksimum (X max) & 100 & 95 \\
Mean & 85,09 & 76,69 \\
Median & 86,00 & 76,00 \\
Modus & 76,00 & 76,00 \\
Simpangan baku & 9,47 & 12,72 \\
Varian & 89,67 & 161,75 \\
\hline
\end{tabular}

Dapat dilihat dari Tabel 4 bahwa kelompok eksperimen yang menggunakan model pembelajaran Creative Problem Solving (CPS) memiliki rata-rata skor akhir yang lebih tinggi dibandingkan dengan rata-rata kelompok kontrol yang menggunakan model konvensional. Dari hasil perhitungan SPSS 22 diperoleh nilai sig=0,003 maka $H_{0}$ ditolak, sehingga dapat disimpulkan bahwa ada pengaruh yang signifikan model pembelajaran Creative Problem Solving (CPS) terhadap kemampuan literasi matematis siswa di SMA Negeri 6 Prabumulih.

Model pembelajaran Creative Problem Solving (CPS) adalah suatu variasi dari pembelajaran dalam mengorganisasikan gagasan kreatif dan penguatan keterampilan untuk menyelesaikan suatu permasalahan. Proses pembelajaran pada model pembelajaran Creative Problem Solving (CPS) dengan memberikan Lembar Kerja Siswa (LKPD), siswa dibentuk menjadi 6 kelompok yang terdiri dari 5-6 orang siswa, kelas yang digunakan adalah kelas XI.MIPA.3. Siswa berusaha mencari jawaban dengan cara berdiskusi bersama kelompoknya. Pada pertemuan pertama hampir semua kelompok masih kesulitan dalam menjawab pertanyaan yang ada di Lembar Kerja Siswa (LKPD) pada setiap langkah kemampuan literasi matematis. Pada pertemuan kedua dan ketiga siswa sudah memahami setiap langkah Lembar Kerja Siswa (LKPD). Model pembelajaran Creative Problem Solving (CPS) menuntun siswa untuk bekerja sama secara optimal. Pada LKS yang berbasis CPS menyatakan bahwa LKS agar mengarahkan siswa dalam memecahkan masalah (Taufik, 2015). Selain itu pembelajaran secara berkelompok membuat siswa saling bertukar suatu pikiran dalam menyelesaikan masalah sehingga siswa akan menjadi lebih aktif serta memahami dalam suatu proses pembelajaran.

Dalam penelitian ini model pembelajaran Creative Problem Solving (CPS) telah diterapkan secara ketat dengan langkah-langkah sesuai petunjuk Shoimin (2014) sebagai berikut: a) Tahap klarifikasi masalah, pada tahap ini setiap kelompok bekerjasama dan terlihat lebih aktif untuk memahami materi. Dengan suatu arahan dari guru dan bantuan LKPD, siswa dapat memahami tentang penyelesaian seperti apa yang akan dilakukan untuk masalah yang diajukan atau diberikan. Siswa dengan kemampuan tinggi ikut memberikan pemahaman kepada siswa dengan kemampuan rendah; b) Tahap pengungkapan pendapat, setiap kelompok cukup antusias dalam menyelesaikan masalah yang diberikan walaupun beberapa kelompok merasa kesulitan menyelesaikannya. Karena pada tahap ini siswa dibebaskan untuk mengungkapkan pendapat tentang berbagai macam strategi penyelesaian masalah yang diajukan; c) Tahap evaluasi dan pemilihan, setiap kelompok kembali mendiskusikan pendapat-pendapat atau strategi mana yang tepat untuk menyelesaikan masalah yang diberikan; d) Tahap implementasi, setiap kelompok telah menentukan strategi yang tepat dan menerapkannya sampai menentukan penyelesaian dari masalah yang diajukan tersebut.

Hasil penelitian ini diperkuat dengan penelitian sebelumnya oleh Wahyuni dkk (2018) yang menunjukkan terdapat perbedaan peningkatan kemampuan berpikir kritis matematis antara siswa yang mendapatkan model pembelajaran Creative 
Problem Solving dengan siswa yang mendapatkan model pembelajaran langsung (konvensional) pada materi persamaan garis lurus kelas VIII SMP Negeri 12 Singkawang, penelitian Syazali (2015) juga menunjukkan terdapat pengaruh pembelajaran CPS berbantuan Maple 11 terhadap kemampuan pemecahan masalah siswa, dan penelitian Nopitasari (2016) menunjukkan bahwa kemampuan penalaran adaptif matematis dengan model pembelajaran Creative Problem Solving (CPS) lebih tinggi dibandingkan kemampuan penalaran adaptis matematis siswa yang diajar dengan model pembelajaran konvensional.

Berdasarkan hasil penelitian pada Tabel 3 bahwa diketahui nilai rata-rata pada indikator tertinggi yaitu terdapat pada indikator mengidentifikasi fakta-fakta dan merumuskan masalah sebesar 92,38 di kelas eksperimen, hal ini karena siswa pada kelas eksperimen sudah mampu untuk mengidentifikasi masalah dan mengetahui apa yang ditanyakan. Siswa telah dilatih menggunakan pembelajaran Creative Problem Solving (CPS) dengan diberikan suatu masalah kemudian diminta untuk mencari solusi dari permasalahan tersebut melalui fase klarifikasi masalah. Sedangkan nilai rata-rata pada indikator tertinggi di kelas konvensional sebesar 86,19, hal ini menunjukkan bahwa siswanya juga telah memiliki kemampuan untuk mengidentifikasi fakta-fakta serta merumuskan masalah pada soal yang diberikan.

Selain itu, diketahui juga nilai rata-rata pada indikator terendah yaitu terdapat pada indikator menegaskan dan menarik kesimpulan dari satu kasus berdasarkan sejumlah data yang teramati sebesar 75,24 di kelas eksperimen, hal ini disebabkan oleh siswa sulit untuk menggabungkan pengetahuan yang diperoleh menjadi pengetahuan yang utuh untuk diimplementasikan dalam permasalahan matematika. Pada kelas eksperimen, siswa yang diajarkan menggunakan model Creative Problem Solving (CPS) masih mengalami kesulitan pada fase implementasi sehingga berdampak pada rendahnya indikator menegaskan dan menarik kesimpulan. Sedangkan nilai rata-rata pada indikator terendah di kelas konvensional sebesar 60 , hal ini karena pada pembelajaran konvensional, ada beberapa siswa cenderung tidak memeriksa kembali jawaban yang mereka dapatkan dan masih banyak siswa yang keliru dalam perhitungan serta masih banyak juga siswa yang tidak menarik kesimpulan di akhir dari penyelesaian soal tersebut.

Jadi model pembelajaran Creative Problem Solving (CPS) yang diterapkan pada proses pembelajaran dapat meningkatkan kemampuan literasi matematis karena siswa lebih aktif dalam menyelesaikan masalah yang diberikan pada soal. Hal tersebut sejalan dengan penelitian sebelumnya yang menunjukkan bahwa kemampuan literasi matematis yang diajarkan dengan model pembelajaran CPS berbantuan Hand on Acitivity lebih baik daripada kemampuan literasi matematis pada kelas yang diajar dengan model pembelajaran konvensional (Fitriyani dan Mastur, 2017). Penelitian Jufri (2018) juga menunjukkan bahwa peningkatan kemampuan literasi matematis level 3 siswa untuk kategori KAM tinggi dan sedang kelas eksperimen yang diberi perlakuan Doubel Loop Problem Solving lebih baik daripada siswa kelas kontrol untuk kategori KAM tinggi dan sedang yang memperoleh pembelajaran secara konvensional.

Secara keseluruhan berdasarkan data hasil penelitian, model pembelajaran Creative Problem Solving (CPS) memberikan pengaruh yang lebih baik terhadap kemampuan literasi matematis level 3 dibandingkan menggunakan pembelajaran konvensional. Pembelajaran CPS melibatkan siswa dapat lebih aktif dan berpikir optimal dalam menyelesaikan masalah, model pembelajaran CPS mengutamakan 
proses dari setiap langkah pada mengidentifikasi dan merumuskan masalah, strategi yang digunakan pada tahapan penyelesaian masalah, melaksanakan perhitungan berdasarkan aturan atau rumus tertentu, dan menegaskan menarik kesimpulan dari satu kasus berdasarkan sejumlah data yang teramati pada permasalahan tersebut.

\section{SIMPULAN}

Berdasarkan rumusan masalah, hasil penelitian, dan pembahasan diperoleh bahwa kemampuan literasi matematis level 3 siswa dengan menggunakan model pembelajaran Creative Problem Solving (CPS) lebih tinggi daripada kemampuan literasi matematis level 3 siswa yang menggunakan pembelajaran konvensional, maka dapat disimpulkan bahwa ada pengaruh yang signifikan penerapan model pembelajaran Creative Problem Solving (CPS) terhadap kemampuan literasi matematis siswa di SMA Negeri 6 Prabumulih.

\section{DAFTAR PUSTAKA}

Abidin, Y., Mulyati, T., dan Yunansah, H. 2017. Pembelajaran Literasi: Strategi Meningkatkan Kemampuan Literasi Matematika, Sains, Membaca dan Menulis. Jakarta: Bumi Aksara.

Antika, R. 2015. Pembelajaran Matematika Kontekstual untuk Meningkatkan Literasi Matematis dan Motivasi Belajar Siswa SMP. Disertasi tidak diterbitkan. Bandung: Universitas Pendidikan Indonesia.

Effendy, M. Hadapi Revolusi Industri 4.0 Kemendikbud Buat Lima Kompetensi. Harian Jawa Pos, 2 Mei 2018 halaman 7.

Fathani, A.H. 2016. Pengembangan Literasi Matematika Sekolah dalam Perspektif Multiple Intellogences. Edu Sains: Jurnal Pendidikan Sains \& Matematika, Vol. 4(2) : 136-149.

Fitriyani, I. dan Mastur, Z. 2017. Kemampuan Literasi Matematika Siswa Ditinjau dari Kecerdasan Emosional Pada Pembelajaran CPS Berbantu Hand On Activiy. Unnes Journal of Mathematics Education Research, Vol. 6(2) : 139147.

Gray, A. et all. 2016. The 10 Skill You Need to Thrive in the Fourth Industrial Revolution. [Online].

Tersedia: https://www.weforum.org/agenda/2016/01/the-10-skills-you-need-to-thrive-inthe-fourth-industrial-revolution/ [24 April 2019]

Jufri, L.H. 2014. Penerapan Double Loop Problem Solving untuk Meningkatkan Kemampuan Literasi Matematis dan Self-Efficacy Siswa Sekolah Menengah Pertama. Disertasi tidak diterbitkan. Bandung: Universitas Pendidikan Indonesia.

Jumarniati, J., Pasandaran, R.F., dan Riady, A. 2016. Kemampuan Literasi Matematika dalam Menyelesaikan Masalah Turunan Fungsi Trigonometri. Pedagogy:Jurnal Pendidikan Matematika, Vol. 1(2) : 66-75.

Kemendikbud. 2016. Survei International PISA. [Online]. Tersedia: (http://litbang.kemendikbud.go.id/index.php/survei-internasional-pisa/). Maret 2019]

Kesumawati, N. dan Aridanu, I. 2018. Statistik Parametrik Penelitian Pendidikan. Cetakan Kedua. Palembang: Noer Fikri. 
Nopitasari, D. 2016. Pengaruh Model Pembelajaran Creative Problem Solving (CPS) Terhadap Kemampuan Penalaran Adaptif Matematis Siswa. Mathline: Jurnal Matematika dan Pendidikan Matematika, Vol. 1(2) : 103-112.

OECD. 2015. PISA 2015 Draft Mathematics Framework. Paris: OECD Publishing.

OECD. 2015. PISA 2015 Result Excellence and Equity In Education (Volume 1). Paris: OECD Publishing.

Ojose, B. 2011. Mathematics Literacy: Are We Able To Put The Mathematics We Learn Into Everyday Use. Journal of Mathematics Education, Vol. 4(1) : 89100.

Perdana. 2019. Tingkatan Kemampuan Literasi Matematika di Era Revolusi Industri 4.0. [Online]. Tersedia: (https://radarsolo.jawapos.com/read/2019/03/20/126411/tingkatkankemampuan-literasi-matematika-di-era-revolusi-industri-4.0/2. [24 April 2019]

Putra, Y.Y., Zulkardi, dan Hartono, Y. 2016. Pengembangan Soal Matematika Model PISA Level 4, 5, 6 Menggunakan Kontek Lampung. Kreano, Jurnal Matematika Kreatif-Inovatif, Vol. 7(1) : 10-16.

Shiel, G., Perkins, R., Close, S., and Oldham, E. 2007. PISA Mathematics: a Teacher's Guide. Dublin: Stationery Office.

Shoimin, A. 2014. 68 Model Pembelajaran Inovatif dalam Kurikulum 2013. Yogyakarta: Ar-Ruzz Media.

Stacey, K. 2011. The PISA View of Mathematical Literacy in Indonesia. Journal on Mathematics Education, Vol. 2(2) : 95-126.

Sugiyono. 2017. Metode Penelitian Pendidikan Pendekatan Kuantitatif, Kualitatif, dan $R \& D$. Bandung: Alfabeta.

Syazali, M. 2015. Pengaruh Model Pembelajaran Creative Problem Solving Berbantuan Media Maple 11 Terhadap Kemampuan Pemecahan Masalah Matematis. Al-Jabar: Jurnal Pendidikan Matematika, Vol. 6(1) : 91-98.

Taufik, M.A. 2015. Pengembangan Lembar Kerja Siswa (LKS) Berbasis Creative Problem Solving (CPS) Pada Pokok Bahasan Fungsi Kelas VIII SMP. Skripsi tidak diterbitkan. Purwokerto: Universitas Muhammadiyah Purwokerto.

Wahyuni, R., Mariyam, M., dan Sartika, D. 2018. Efektivitas Model Pembelajaran Creative Problem Solving (CPS) Dalam Meningkatkan Kemampuan Berpikir Kritis Matematis Siswa Pada Materi Persamaan Garis Lurus. JPMI (Jurnal Pendidikan Matematika Indonesia), Vol. 3(1) : 26-31. 